\title{
ENGINEERING VASCULARISED TISSUES IN VITRO
}

\author{
N.C. Rivron *, J. Liu, J. Rouwkema, J. de Boer, C.A. van Blitterswijk \\ Institute for BioMedical Technology, Department of Tissue Regeneration, University of Twente, Zuidhorst, P.O. Box \\ 217, 7500 AE Enschede, The Netherlands
}

\begin{abstract}
Tissue engineering aims at replacing or regenerating tissues lost due to diseases or traumas (Langer and Vacanti, 1993). However, mimicking in vitro the physiological complexity of vascularized tissue is a major obstacle, which possibly contributes to impaired healing in vivo. In higher organisms, native features including the vascular network, the lymphatic networks and interstitial flow promote both mass transport and organ development. Attempts to mimic those features in engineered tissues will lead to more clinically relevant cell-based therapies. Aside from current strategies promoting angiogenesis from the host, an alternative concept termed prevascularization is emerging. It aims at creating a biological vasculature inside an engineered tissue prior to implantation. This vasculature can rapidly anastamose with the host and enhances tissue survival and differentiation. Interestingly, growing evidence supports a role of the vasculature in regulating pattern formation and tissue differentiation. Thus, prevascularized tissues also benefit from an intrinsic contribution of their vascular system to their development. From those early attempts are emerging a body of principles and strategies to grow and maintain, in vitro, those self-assembled biological vascular networks. This could lead to the generation of engineered tissues of more physiologically relevant complexity and improved regenerative potential.
\end{abstract}

Key Words: tissue engineering, vascular system, prevascularization

*Address for correspondence:

N.C. Rivron

Institute for BioMedical Technology, Department of Tissue

Regeneration,

University of Twente

P.O. Box 217,

7500 AE Enschede,

The Netherlands

E-mail: nicolasrivron@gmail.com

\section{Introduction}

Tissue engineering applies the principles of engineering and life sciences toward the development of biological substitutes that restore, maintain, or improve tissue function or a whole organ (Langer and Vacanti, 1993). Today's successes, in this field, are limited to avascular (cartilage) or thin tissues (skin, bladder) with slow metabolism, which rely on either diffusion or quick angiogenesis due to an inflammatory wound-healing response. Engineering more complex tissues necessitate growing a vasculature that promotes cell survival, tissue organization and rapid vascularization following implantation.

In the adult, the vascular system forms an extensive, highly branched and hierarchically organized network. It is a major regulator of homeostasis through the mass transport of gas, liquids, nutrients, cells, signalling molecules and waste products. Besides this classical wellknown function, roles of the vascular system in shortand long-range communication between organs and in tissue differentiation have been proposed and are still debated. Interesting reports suggest that, following trauma and in response to tissue ischemia and cytokines, bone marrow derived stem or progenitor cells are recruited to the circulation (Asahara et al., 1997). Increasing evidence show they may, then, contribute to vascular healing and pathologic postnatal neoangiogenesis (Asahara et al., 1999a; Asahara et al., 1999b; Crosby et al., 2000; Lyden et al., 2001; Heissig et al., 2002; Edelberg et al., 2002; Urbich et al., 2003; Bailey et al., 2004; Shi et al., 1998; Gill et al., 2001; Rajantie et al., 2007). In recent years, clues accumulated to describe a role of the vasculature in the development or healing of tissues. Roles in the maturation of the myocardium (Stainier et al., 1995; Kramer et al., 1996; Meyer et al., 1995) or in bone development and healing (Carano and Filvaroff, 2003) are relevant of this wider, intrinsic, utility. Those still controversial early studies (Rajantie et al., 2007; Wagers et al., 2002; De Palma et al., 2003; Voswinckel et al., 2003; Ziegelhoeffer et al., 2004; He et al., 2004), reveal multiple functions of the vascular system (Red-Horse et al., 2007). They more generally depict the important place of the vascular system in homeostasis and in tissue repair and, thus, emphasize its potential contribution to engineer and regenerate complex tissues.

\section{Physiological and Pathological Aspects of the Vascular System}

During embryonic development, morphogenesis of the vascular system occurs by vasculogenesis (de novo 
Table 1: Phenotype of some knock-out mice

\begin{tabular}{|c|c|c|c|}
\hline Knock-out gene & Lethality & Vessel phenotype & Reference \\
\hline VEGF-A & Embryonic lethal on E10.5 & $\begin{array}{l}\text { VEGF+/- and VEGF+/+ phenotypes present disruption, but no abolition, of } \\
\text { blood island differentiation; impaired lumen formation and vessel organization }\end{array}$ & $\begin{array}{l}\text { Carmeliet et al., 1996; Ferrara et al., } \\
1996\end{array}$ \\
\hline VEGF-B & Alive & $\begin{array}{l}\text { Disruption of the atrial conduction. Hearts with reduced size and vascular } \\
\text { dysfunction, impaired recovery }\end{array}$ & $\begin{array}{l}\text { Aase } \text { et al., } 2001 \\
\text { Bellomo et al., } 2000\end{array}$ \\
\hline VEGFR1 & Embryonic lethal on E8.5 & Correct differentiation of EC but impaired assembly & Fong et al., 1995 \\
\hline VEGFR2 & Embryonic lethal on E8.5 & $\begin{array}{l}\text { Defect in the development of haematopoietic and endothelial cells. Absence of } \\
\text { blood island and reduced haematopoietic precursors }\end{array}$ & Shalaby et al., 1995 \\
\hline VEGFR3 & Embryonic lethal on E9.5 & $\begin{array}{l}\text { Defective blood vessel development, large vessels with abnormal organization } \\
\text { and defective lumens }\end{array}$ & Dumont et al., 1998 \\
\hline Ang1 & Embryonic lethal on E10.5 & Lack of vessel remodeling, dilated vessel & Suri et al., 1996 \\
\hline Tie2 & Embryonic lethal & Lack of vessel remodelling & Sato et al., 1995 \\
\hline Ang2 overexpression & Embryonic lethal & Disrupts blood vessel formation & Maisonpierre et al., 1997 \\
\hline PDGF-B or PDGF $\beta R$ & $\begin{array}{l}\text { Embryonic lethal at E17.5 or } \\
\text { death at birth }\end{array}$ & Hemorrhagic phenotype due to a lack of Stabilization of the vessels by MC & $\begin{array}{l}\text { Leveen et al., 1994; Lindahl et al., } \\
\text { 1997; Soriano, } 1994\end{array}$ \\
\hline TGFß1, & $\begin{array}{l}50 \% \text { embryonic death in TGF } \\
\text { beta } 1-/-\end{array}$ & $\begin{array}{l}\text { Impaired EC differentiation due to inadequate capillary tube formation, and } \\
\text { weak vessels with reduced cellular adhesiveness }\end{array}$ & Dickson et al., 1995 \\
\hline TGFßR2 & Embryonic lethal on E10.5 & Defects in the yolk sac hematopoiesis and vasculogenesis, & Oshima et al., 1996 \\
\hline Endoglin & Embryonic lethal on E11.5 & Poor vascular smooth muscle development and arrested endothelial remodeling & Li et al., 1999 \\
\hline a5ß1 integrins and fibronectin & & Distended blood vessels, reduced blood vessel pattern complexity & Francis et al., 2002 \\
\hline
\end{tabular}

formation of blood vessels). The first arrangement is believed to be blood islands formed by angioblasts that fuse and sprout to form a primary plexus (Drake et al., 1998). The vasculature then expands by both vasculogenesis and angiogenesis. Vasculogenesis was historically believed to take place only during embryonic development. It was proven in 1997 that vasculogenesis also occurs during adult life and is involved in remodelling the vascular tree (Asahara et al., 1999a; Asahara et al., 1999b). Angiogenesis is the sprouting, bridging or intussusceptive growth of existing vessels. All vessels are formed by endothelial cells (EC), extracellular matrix (ECM) and mural cells (MC). More complex structures can also include fibroblasts. The EC create an active nonthrombogenic, permeable layer in contact with blood. Endothelial tubes are stabilized by MC (either pericytes for capillaries or vascular smooth muscle cells for bigger vessels). A basement membrane (ECM) and elastic laminae (arterioles and venules) is embedding the two cell types. Recent efforts led to important discoveries on the molecular regulation of blood capillary formation. Two excellent reviews provide extended information on this subject (Jain, 2003; Adams and Alitalo, 2007). Studies on knock-out mice are an interesting starting point and provide some insight into this molecular regulation (see Table 1). These studies emphasize that vascularization involves a complex spatio-temporal regulation through several molecules providing a balance between the activation of endothelial cells to expand or replace the vasculature and the interaction of endothelial cells with mural cells to ensure a stable, functional vasculature. The sequence of events during adult angiogenesis includes the vasodilatation of the parental vessel, the degradation of the basement membrane through movements of endothelial cells (EC) and action of proteolytic enzymes, the migration and proliferation of endothelial cells to form a cord-like structure mainly under the control of different VEGF isoforms and bFGF, the formation of lumen and tube-like structures under the control of at least angiopoietins 1 and 2 , and the stabilization of the capillaries by recruitment of mural cells under the control of at least TGF $\beta 1$ and PDGFBB (Hirschi et al., 2002). This layer of MC promotes stability and functionality of vessels. It synthesizes a basement membrane and stabilizes the structure. MC secrete VEGF as a survival factor for the endothelium (Jain, 2003; Reinmuth et al., 2001) and finally MC regulate perfusion through vasomotion making vessels less prone to regression (Hellstrom et al., 2001; Koike et al., 2004). The vascular network is hierarchically structured such that arterial vessels typically exposed to high pressure and flow and adapted for mass transport are branching into arterioles and capillaries. Capillaries are embedding tissues and represent the most abundant network in the body. Due to the structure of capillary walls, they are the main site of gas and nutrient exchange. Capillaries are highly heterogeneous and are present in very different tissuespecific forms and functions (Conway and Carmeliet, 2004; Armulik et al., 2005). Following the exchange of nutrient and waste with the target tissue, capillaries converge into venules and veins exposed to lower pressure and characterized by larger lumen and specific structures (i.e., valves). Interestingly, the vascular system has a low turnover rate but is very responsive and adaptive to stimuli. Endothelial cells divide approximately every 3 years and, in cases such as retinal vessels, every 14 years (Polverini et al., 2002). The vascular system mostly remains in a quiescent or very steadily changing state; however few cases, either chronic or pathologic, entail remodelling processes: (i) in the female reproduction cycle, massive angiogenesis occurs every 28 days to prepare a highly vascularized endometrium as a niche for fertilized eggs; (ii) in cancer, impaired angiogenesis constantly occurs at tumour sites where immature vessels are selectively obliterated as a consequence of VEGF withdrawal (Benjamin et al., 1999). Besides a normal steady turn-over, rapid remodelling happens at critical sites such as tumours or wound healing sites, which are of particular scientific interest to understand mechanisms of vessels formation and regression.

A deregulation of the well-balanced growth, resorption or turn-over of the vascular system is implicated in an evergrowing list of pathologies (70 examples reported by Carmeliet, 2005; Carmeliet and Jain, 2000). Typical examples involve abnormal/excessive angiogenesis or insufficient angiogenesis and vessel regression. Diabetic retinopathy and retinopathy of prematurity is due to impaired leaky vessels that are prone to haemorrhage (Campochiaro, 2004). Reduced angiogenesis aggravates 
ischemic heart disease and results in impaired regeneration (Jesmin et al., 2005; Shiojima et al., 2005). Osteoporosis is partly due to low VEGF (Pufe et al., 2003) and to agedependent decline of VEGF-driven angiogenesis (Martinez et al., 2002). Impaired bone fracture healing and bone formation is partly due to angiogenesis inhibitors that prevent fracture healing (Yin et al., 2002) or insufficient angiogenesis (Hausman et al., 2001; Carmeliet and Jain, 2000). The connections between angiogenesis and diseases along with the cellular and molecular regulation of capillary formation and remodelling are currently under intense investigations. However, the formation of mature and functional capillaries in the context of the structural and mechanical complexity of tissues remains partly unknown. There is, for instance, a great challenge in depicting the cells and their molecular and mechanical interplay resulting in the vascular tissue pattern formation on large scale ( $\mathrm{mm}$ scale) and its effect on the organization of surrounding tissues. This interest is driven by the possibility to built, in vitro, relevant models of a vascularized tissue for therapeutic drug testing but also in tissue engineering and tissue regeneration to vascularize implants and thus enhance the success of grafting. Judah Folkman posed the question whether angiogenesis could be an "organizing principle in biology and medicine" (Folkman, 2007) and this is under particular investigation in the attempt to vascularize engineered tissues in vitro.

\section{Nutrient Limitation}

Nutrient limitation is a classical issue in the field of tissue and organ transplantation. It received wide attention of scientists and clinicians following the work of Folkman (Folkman, 1971) on the "dormant diameter" of in vitro tumour cultures. Folkman suggested that tumours could not exceed a critical size, without connection to the vascular system, due to limited diffusion. Actually in 1961, Greene demonstrated this point by showing that the implanted tumour re-grew after being switched into a richer environment (Greene, 1961). Following these studies, more and more researches revealed that the nutritional problems are not limited to tumours, but play a role in the transplantation of many tissues and organs. Physiological studies show that capillaries are spaced by $200 \mu \mathrm{m}$ maximum thus suggesting a range for diffusion in vivo (Colton, 1995; Moldovan, 2005). Tissues need newly formed blood vessels or capillaries to pass through it for the delivery of nutrients.

Nutrient limitations also apply to cell-based tissue engineering. When the task in this field moves "from lab bench to the clinic", a new challenge appears due to the clinical relevant size of the tailored tissue. In order to get thick tissue, more living cells should be used. From above, it is already known that cell survival upon implantation in vivo is one of the limiting factors for tissue regeneration. So far, there are already several engineered-substitutes applied clinically, such as skin, cartilage, and large-scale vasculature (Brittberg et al., 1994; Kirsner et al., 1998; Shin'oka et al., 2001). But in other disciplines, like bone, muscle, myocardium etc, the application is limited and the amount of tissue formed is small due to central necrosis, which is at least partly due to a lack of cell survival (Kruyt et al., 2004; Ishaug-Riley et al., 1998; Suzuki et al., 1998; Griffith et al., 2005).

When cells are implanted in vivo, nutrition support comes from the adjacent host blood vessels. For big grafts (more than several hundreds of millimeters), the constructs need their own blood vessels and capillaries to provide nutrition and waste transport to and from the tissue. After implantation, blood vessels from the host will invade the implant. However, it takes days to develop the new vasculature network in the graft from host blood vessels (Griffith and Naughton, 2002), which means that during this reconstructive period, the cells far from the host capillaries experience nutrient limitations, which can result in cell death. When the graft has been vascularized, the cells that survived can proliferate and expand again. Therefore, the formation of new blood vessels, or vascularization, is an important issue in tissue engineering (Mooney and Mikos, 1999; Tsai et al., 2003).

\section{Hypoxia}

Among the limiting factors, oxygen consumption is high, whereas the availability of other nutrients, like glucose and amino acids, is comparatively better than that of oxygen. It is widely accepted that oxygen is a limiting factor in cell survival in most grafts. (Muschler et al, 2004). In cardiac tissue engineering, heart cells critically demand oxygen supply, and the thickness of tissue formed critically corresponded to the oxygen diffusion (Carrier et al., 1999, 2002; Lewis et al., 2005; Papadaki et al., 2001; Radisic et al., 2004a b, 2006). Interestingly, hypoxia-derived elements stabilize VEGF mRNA and increase VEGF mRNA transcription, thus acting as an indirect stimulator for the angiogenesis/vasculogenesis in vivo (Levy et al., 1996; Shima et al., 1995; Stein et al., 1995; Shweiki, 1992). Recently, Hung et al. demonstrated that short-time hypoxia $\left(1 \% \mathrm{O}_{2}\right)$ treatment of hMSCs enhanced their engraftment in vivo (Hung et al., 2007), suggesting that short-term exposure to hypoxia before transplantation might be a simple way to improve the transplant survival.

\section{Growing Vasculatures in Engineered Tissues}

Engineering complex tissues requires, among other things, a hierarchical vascular network inducing rapid and stable perfusion of the implant. This is a current limitation in engineering tissues of clinically relevant size and complexity. In addition to mass transport properties, clues are accumulating to depict an intrinsic role of the vascular system in the regulation of tissue formation and tissue differentiation (Lammert et al., 2001; Beaudry et al., 2007; Maes et al, 2004; Hausman and Rinker, 2004; Mori et al., 1998). In a more general way, the penetration of vessels into a tissue allows the transport of molecules or cells (i.e. macrophages or EPC) regulating, for instance, wound healing or tissue survival. This makes the vascular system, intrinsically or not, a crucial player in the normal development of a tissue. Ideally, the vascularization of in 
vitro-generated implants should follow a hierarchical network and include consecutively a vessel allowing microsurgical connection to the host vasculature $(\sim 1 \mathrm{~mm}$ diameter) linked to smaller branches mimicking arterioles or venules (80 to $100 \mu \mathrm{m}$ ) and leading to a capillary tree (10 to $15 \mu \mathrm{m}$ ) embedded in the tissue. Typically, the main vessels can be constructed using classical tissue engineering approaches by building multiple layered tubes of synthetic and biological material (Kannan et al., 2005; L'Heureux et al., 2006) and lately, two studies investigated the fabrication of intermediate sizes $(50-150 \mu \mathrm{m})$ vessels with new approaches (Chrobak et al., 2006; Ko and Iwata, 2001). These smaller structures (arterioles and capillaries) however are, until now, too small to be fabricated and need to be generated by self-assembly and self-organization of multicellular systems. Two strategies are developed to grow capillaries in an implant: (i) by promoting invasion of vessels from the host by combining the implant with tools including drug release, functionalized matrices or by surgical techniques or (ii) by forming, de novo, a vascular network in the construct before implantation. This is achieved by orchestrating the proper cascade of events in vitro. This field of investigation is very active to develop tissue constructs with engineered capillary networks, which promotes a more rapid perfusion and improved survival and differentiation of the associated tissue. There is, therefore, an important interest in further development of those self-assembled prevascularized tissues. Below, we will briefly describe general strategies and requirements to promote vascularization of tissue engineered constructs through angiogenesis. We will then depict studies relating the generation of a capillary bed by vasculogenesis, in different in vitro-generated tissues.

\section{Current Technological or Surgical Approaches: Promoting Angiogenesis}

Depicting the natural assembly of a vascular system emphasizes the importance of a tight spatial and temporal orchestration of the cells and molecules involved. New vessels must undergo different stages of assembly, maturation and remodelling before becoming stable and functional. This can be achieved by promoting invasion and sprouting of the host vasculature into the implant through angiogenesis.

\section{Drug Delivery}

Drug delivery is an attractive way to promote angiogenesis. Technologies for the sustained and localized release of molecules were developed through, for instance, the encapsulation of molecules in synthetic polymers (Murphy et al., 2000). Interestingly, therapeutic angiogenesis assays using gene delivery demonstrated that a single factor might not be sufficient to form mature functional vessels (Losordo et al, 2002; Isner et al., 1996). It is essential to promote at least part of the subsequent stages of remodelling, beginning with the stabilization of the vessel with MC. Thus, a cocktail of mitotic and differentiating agents that is properly delivered is critical. Controlling the dose, rate and presentation of those factors is a huge challenge and this necessity led to important technological developments such as dual factor release systems (Richardson et al., 2001). The slow release of two factors over different time period promoted angiogenesis through the sprouting of local vessels (first step under the control of VEGF) and their stabilization by recruited pericytes (second step under the control of PDGF-BB) (Richardson et al., 2001). The infiltration of the host vessels is strong and the vessels are mature, but vascularization is still gradual and relatively slow (more than 2 weeks). Another technological approach is the development of artificial functionalized ECM networks. Biomaterials have been developed which bind molecules using the natural affinity of certain growth factors for heparin or fibrin. This allows a cell-based release of molecules and a remodelling of the ECM coupled to the morphogenetic process. It was proven efficient to guide the sprouting of endothelial cells (Lutolf et al., 2003). Interestingly, those strategies could lead to applications for the vascular system at both macroscale to prevent restenosis after stent implantation and at microscale to promote the recruitment of microvessels into areas lacking a vasculature. However, finding the minimum number of factors promoting angiogenesis of mature vessels and the adequate spatio-temporal delivery remain a major hurdle. The use of direct factors, besides the lack of precise dosage and pattern of presentation is also limited by a quick degradation and instability of the factors involved. Patricia D'Amore (Darland et al., 2001, Ding et al., 2004) hypothesized that the presentation of the molecules and creation of microgradients are involved in the recruitment of mural cells. This emphasizes the importance of cellcell cross-talk to release the proper quantities in the proper ways (including feed-back loops). One possibility is to target indirectly the angiogenic cascade by triggering genes upstream. This can be achieved using transcription factors or indirect growth factors which play a role more upstream in the hierarchy of the angiogenic process and thus resulting in the over expression of several growth factors involved in the morphogenesis process. An interesting indirect candidate is the pleiotropic factor HIF-1alpha, which up-regulates VEGF, Ang2, PDGF-BB (Carmeliet and Jain, 2000) and promotes increased angiogenesis as shown by angiography and increased blood flow (Vincent et al., 2000). A limit resides in the fact that this endogenous molecule is "tightly regulated by ubiquitination and consequent degradation" (Blau and Banfi, 2001) making it a difficult candidate to work with. Strategies to inhibit its degradation by addition of the PR39 (a peptide, which is naturally produced by macrophages) proved to increase blood flow (Li et al., 2000).

\section{Surgical Technique}

In 1969, Buncke and McLean performed the first microvascular tissue transplant, which started the surgical concept named "flap", which consists of wrapping an implant with a vascularized transplant (McDowell, 1978). This technique promoted vascularization of the wrapped tissue and has been applied to diverse tissues regenerations. (Khouri et al., 1991; Morrison et al., 1990; Terheyden et al., 2001; Terheyden et al., 2004). A clinical study depicting 
the replacement of a mandibular defect in a man successfully used a bone-muscle flap (Warnke et al., 2004). Based on this mechanism, Erol and Spira developed the possibility to grow tissues in vivo around an arterio-venous loop (AV loop) by using artery or vein grafts in a rat model (Erol and Spira, 1979). Morrison et al. further developed the concept by combining the AV-loop with polymer matrices and showed enhanced vascularization of the implant (Hofer et al., 2003; Cassell et al., 2001). By implanting the construct ectopically in a highly vascularized region, the AV-loop promoted vessels ingrowth and led to an in vivo prevascularized tissue engineering implant supporting the survival and differentiation of cells (Messina et al, 2005; Bach et al., 2006). This technique was clinically applied to skin tissue engineering (Tanaka et al., 1996, 2000, 2006) and, in combination with hard porous matrices, promoted the survival of transplanted osteoblasts (Kneser et al., 2006 $a, b, c)$.

\section{First Attempts of In Vitro Prevascularization: Promote Vasculogenesis and Angiogenesis}

An alternative concept termed prevascularization is rooted in a large body of research on in vitro angiogenesis and aims at creating a vasculature, de novo, from its individual components.

Prevascularization of a tissue consists of promoting the formation of a vascular network inside an engineered tissue, prior to implantation. This can be achieved by culturing, in vitro, relevant cell types (i.e., EC, MC and tissue-related cell types) and recapitulating some developmental processes typical of vasculogenesis. Prevascularization is, among others, dependent on the EC/ $\mathrm{MC}$ source and their phenotypic stability, the EC/MC interaction with the tissue-related cell types, the stability of the neovascular structures and the interaction with the biomaterial. The aim is to combine the implant with a functional vascular network prior to implantation to promote survival, differentiation and integration of the engineered tissue or as an intermediate form playing a role to accelerate regeneration of the final tissue. Below, we will discuss the current status of prevascularisation in different tissues.

\section{Skin}

The in vitro formation of microvessels within an engineered tissue was, to our knowledge, first described by Black et al. (1998). A skin equivalent was fabricated by co-culturing dermal fibroblasts, keratinocytes and human umbilical vein endothelial cells (hUVEC) on chitosan/collagen scaffolds. A tubular network formed by self-organization of EC in cooperation with fibroblasts. It included lumen with typical intercellular junctions, WeibelPalade bodies in EC and a basement membrane of laminin and collagen IV. The skin tissue self-organized into strata with a pseudo-basal layer, stratum spinosum and stratum granulosum (Black et al., 1998). In a similar engineered skin construct (Tremblay et al., 2005), the presence of microvessels accelerated the implant's perfusion in vivo (4 vs. 4-14 days). Interestingly, the perfusion was as fast as for a full human skin transplant. The stabilization of the vessels by MC wasn't investigated but the number of vessels did not significantly decrease after 14 days indicating that the vessels are stable over time. A third study by Shepherd et al. (2006) was performed using human endothelial progenitor cell-derived EC from umbilical cord blood, EPCs from adult peripheral blood (habEPC-EC) or hUVEC (Benjamin et al., 1999). Keratinocytes were first cultured in a decellularized human dermis. The endothelial cells were then seeded on the deep surface of the graft. Microvessels formed and underwent maturation and stabilization by MC derived from SMC (Schechner et al., 2000; Yang et al., 2001). No in vitro data could assess the functionality of the construct (Shepherd et al., 2006).

\section{Bone}

The interaction between bone and the vascular system is well described (Carano and Filvaroff, 2003) and of particular interest for bone prevascularization. Reciprocal interactions between bone and vascular-related cells includes the production of BMP2, endothelin-1 and insulinlike growth factor by EC (Bouletreau et al., 2002; von Schroeder et al., 2003; Villars et al., 2000) and the production of VEGF by osteoblasts with an effect on EC survival, proliferation and differentiation/organization in vitro (Deckers et al., 2000; Furumatsu et al., 2003; Kaigler et al., 2003; Stahl et al., 2004; Wenger et al., 2004; Wang et al., 2004). Interestingly, direct contact (EC/osteoblast) may be essential to form capillary-like structures in 2D and in 3D (Unger et al., 2007; Stahl et al., 2004; Wenger et al., 2004). We demonstrated the possibility to form, in vitro, a prevascular network of cord-like structures in a spherical model of human mesenchymal stem cells (hMSC) and hUVEC. The addition of MC precursors in the form of mouse embryonic fibroblast did not trigger the maturation and stabilization of the network (as compared to skeletal or cardiac muscle systems, see below). Although primitive, this network further maturated, formed lumens in vivo and made connection to the host vasculature after 2 weeks (Figure 4). The interaction of hMSCs with hUVECs, in this system, induced an upregulation of the osteogenic marker alkaline phosphatase suggesting an improved differentiation of the osteoprogenitors (Rouwkema et al., 2006). Elaborating on the work described above, we are currently building models of multicellular spheroids to study vasculogenesis (Figure 13 ). Multiple layer spheroids of different cell types can be built by sequential addition in a hanging drop. Those multicellular spheroids can be used as models to study cell-cell interactions. Unger et al. tested the potential of several biomaterials (porous hydroxyapatite, porous calcium phosphate, porous nickel-titanium and silk fibrin nets) to support vasculogenesis in vitro. Microvessels didn't form when EC (human dermal microvascular endothelial cells, hDMEC) where seeded alone on biomaterials. In co-culture with human osteoblasts (HOC) 


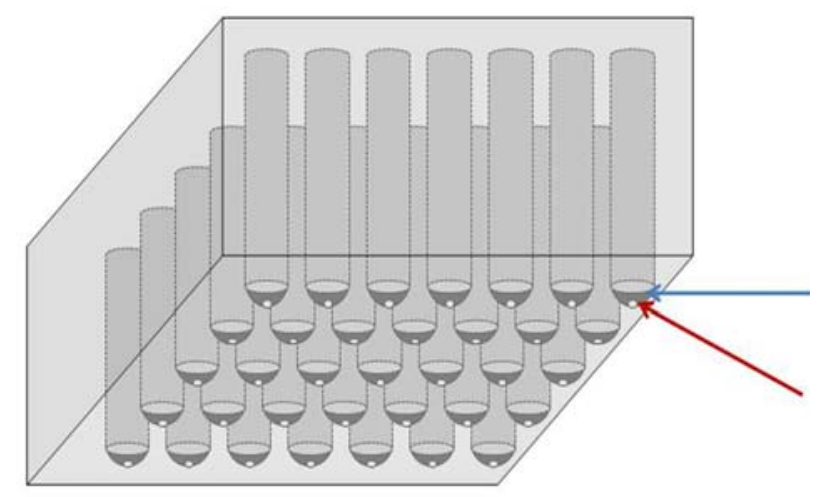

Figure 1: Multicellular spherical system can be grown in drops hanging (blue arrow) from a deep 96 wellplates. Half a million hMSC aggregates at the air-liquid interface (left picture, red arrow).

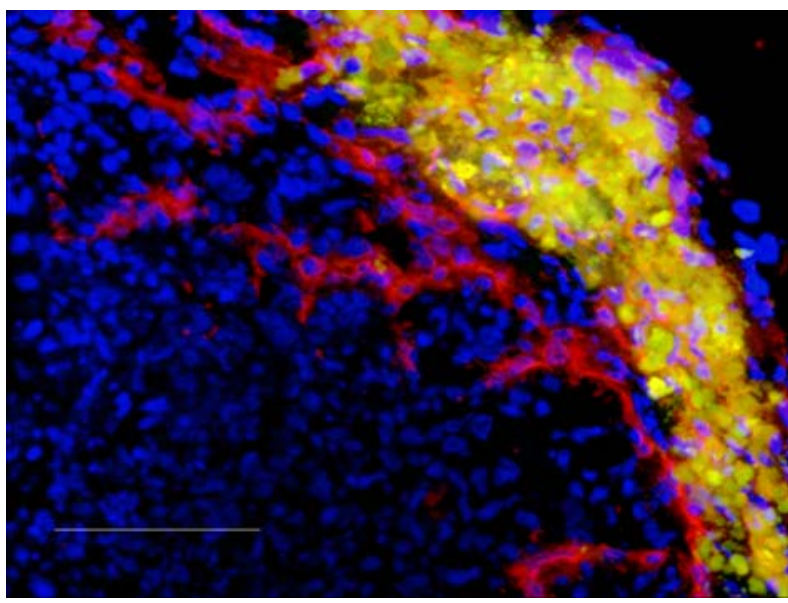

Figure 3: The Sequential addition of hMSC and hUVEC (prelabeled with CFSE, in yellow) lead to multiple layered microtissues. A typical sprouting of precapillary structures appears after five days at the interface between the two populations. All nucleus are stained in blue (DAPI) and red is the endothelial marker cd31. Scale bar: $100 \mu \mathrm{m}$.

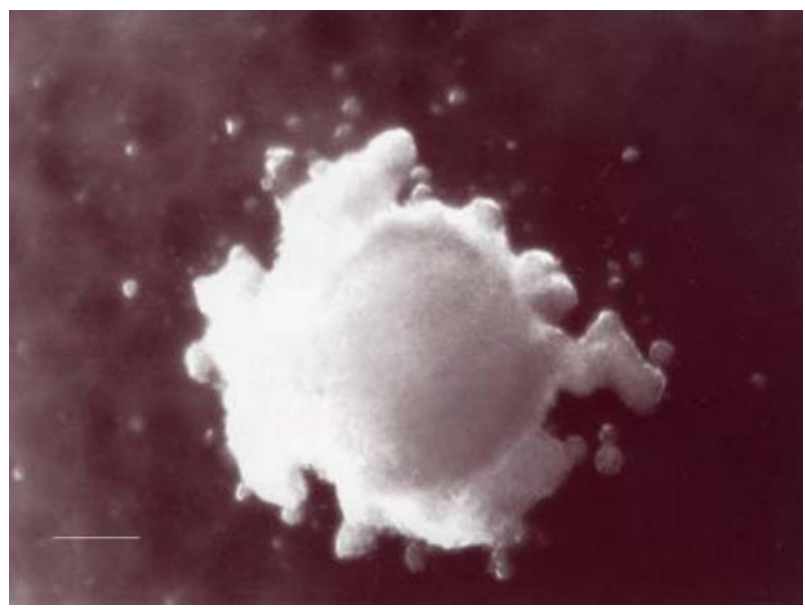

Figure 2: Self assembly of cells at the air-liquid microscope viewed using an inverted microscope after 24 hours. Scale bar: $100 \mu \mathrm{m}$.

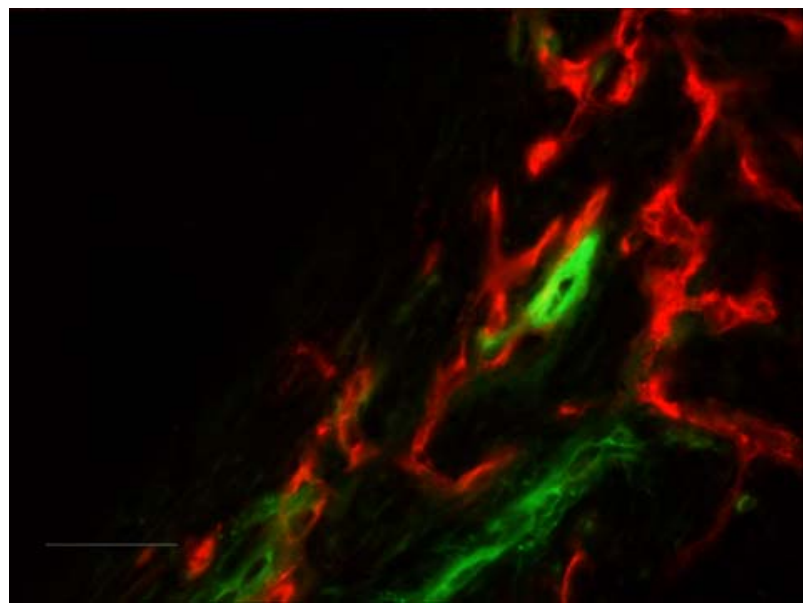

Figure 4: A view of the external part of the scaffold implant. Note the overlapping of the CD31+ structures (in red) and the lectin (in green) demonstrating the anastomosis of the engineered vessels with the host's vasculature. Scale bar: $100 \mu \mathrm{m}$. or with the human osteoblast cell line MG-63, hDMEC formed extensive tubular networks among osteoblasts cells. This suggests that signals from osteoblasts were essential for the formation of those structures and the survival of hDMEC. Interestingly, the addition of angiogenic factors failed to replace the role of osteoblasts. The adequate presentation, distribution and the proper dosage of factors (cell-cell interaction, soluble factors or cell-ECM interaction) leading to EC organization could only be recapitulated by co-culture with osteoblasts. In both studies, the stabilization of the microvessels was not achieved prior to implantation (Unger et al., 2007).

\section{Skeletal Muscle}

A keynote paper by Levenberg et al. (2005) showed the possibility to prevascularize skeletal muscle tissue using endothelial, fibroblast and myoblast cells. EC (hUVEC or human embryonic stem cells derived endothelial cells (hESC-EC)) formed microvessels including lumens in vitro. They were further stabilized in a process mediated by mouse embryonic fibroblasts (mEF). mEFs were recruited around the vascular structures and differentiated into smooth muscle actin-positive mural cells. Their presence increased the local level of VEGF, consistently with in vitro (Darland et al., 2001) and in vivo (Hellstrom et al., 2001; Koike et al., 2004) studies. This adds a substantial clue to the role of MC in the survival and stabilization of vascular structures. A fraction of the mouse skeletal myoblasts cells (C2C12) differentiated into aligned, elongated multinucleated cells similar to muscle fibres. In vivo, the prevascular network anastamosed to the host vasculature within 14 days after subcutaneous, intramuscular or anterior abdominal wall implantation in SCID mice. A precise study of the in vivo performance of the construct proved that prevascularization improved the vascularization, blood perfusion and survival of the engineered tissue (Levenberg et al., 2005). 


\section{Vasa Vasorum}

Wu et al. described a construct using smooth muscle cells and endothelial cells on a porous PGA-PLLA scaffold. A potential application is to fabricate a prevascularized patch as a vasa vasorum for the thick-walled arterial conduit of heart valves. Human SMCs were cultured for 6 days in a PGA/PLLA scaffold before adding, on top of the construct, a layer of human endothelial progenitor cells isolated from cord blood (hcbEPC-EC). The EC invaded the tissue of SMC, assembled into capillary-like structures which were stabilized by mural cells derived from SMC. The interaction of the EC with SMC was essential for EC survival and assembly into microvessels. This study was the first to first described the possibility to use hcbEPCEC as a clinically relevant source of EC for prevascularizing implants (Wu et al., 2003).

\section{Cardiac Muscle}

Caspi et al. designed a muscle construct of cardiomyocytes, EC and fibroblasts for application as a cardiac muscle patch. Cardiomyocytes and EC were human embryonic stem cell-derived (hESC-CM and hESC-EC); fibroblasts were mouse embryonic stem cells (mEF). hUVEC were used as a reference. The co-culture of CM and EC did not lead to organization of EC. Only the tri-culture including the fibroblasts resulted in highly vascularized constructs with capillaries stabilized by mural cells derived from the fibroblasts. Interestingly, the cooperation between the different cell types was accentuated since (i) the fibroblast supported the organization of ECs (EC proliferation, EC density (number and area density of lumen) and (ii) $\mathrm{CM}$ proliferation and differentiation markers were increased by the presence of the other cell types (Caspi et al., 2007). Another interesting study by Kelm et al. depicts the construction of macrotissues using multicellular spheroids as building blocks. Spheroids including human myofibroblasts (hMF) and hUVEC formed primitive vascular structures in vitro. The macrotissues, including or not, this primitive network, were grafted and cultured on top of a chicken embryo's chorioallantoic membrane. Noteworthy, the vasculature of the prevascularized macrotissue developed connections (although limited) with the host as shown by the presence of erythrocytes and improved the graft integration compare to a nonprevascularized macrotissue (rejection, scar tissue, lack of vascularity). A lower expression of VEGF in the prevascularized construct was described as a sign of better oxygenation of the construct (Kelm et al., 2006).

\section{Constructs with Intrinsic Vascularization Potential}

Two studies described the possibility to engineer constructs using biopsies with heterogeneous cell populations including at least an endothelial type and a tissue-related type. Zimmermann et al. demonstrated the possibility to engineer a cardiac muscle with capillary structures from a cardiac neonatal rat biopsy including various cell types. The biopsy was mixed with collagen type I and matrix factors, shaped into a ring and conditioned by mechanical stretching. $\mathrm{CD} 1^{+}$(a platelet and endothelial cell adhesion molecule) vessel-like structures were observed in the tissue in vitro, demonstrating the possibility to grow capillaries in complex tissue directly using a heterogeneous biopsy (Zimmermann et al., 2002). Scherberich et al. presented a bone tissue-engineered construct with vasculogenic potential starting from the heterogeneous stromal vascular fraction of human adipose tissue. The mononuclear fraction of biopsies including mesenchymal progenitors and an endothelial cell type were seeded on porous hydroxyapatite scaffolds and preconditioned in a bioreactor. Interestingly, results show that a fraction of the implanted cells (possibly the $\mathrm{CD} 31^{+}$population) participated, after implantation, in the formation of a vasculature and possibly facilitated or extended the invasion of blood vessels from the host (Scherberich et al., 2007).

\section{Lessons from Those Early Attempts: Emerging Principles and Shared Strategies}

The prevascularization of tissues is a step forward in generating more complex tissues mimicking native tissue physiology or physiopathologies. Combining the engineered tissue with an intrinsic vascular system promotes a rapid perfusion of the implant, independently from its thickness. It proved, in defined systems, to enhance its perfusion, survival and differentiation of the tissue. Of special interest for tissue engineering are the mechanisms underlying the interaction of the endothelium with its microenvironment and the regulation of organ development and pattern formation (Red-Horse et al., 2007). ECs are a source of survival and differentiation factors that could play a role in in vitro preconditioning of the tissue. EC produce pro-inflammatory factors (Peters, 2003) taking part, in vivo, in the inflammatory response. Noteworthy, those early works reveal the prime importance of the tissue-related cell types in the formation of microvessels: (i) a close collaboration between the tissue cell types and the vessel cell types is essential. (ii) The tissue-related cell type is a potential "factory" of signals thus avoiding the addition of molecules (Levenberg et al., 2005; Unger et al., 2007). The prevascularization of a tissue often takes place in the microenvironment (i.e. culture medium) of the tissue involved and the addition of direct angiogenic factors does not improve the capillary formation (Levenberg et al., 2005; Unger et al., 2007). Furthermore, an inadequate exposition to angiogenic factors like VEGF over a long period may results in deformed, non-functional blood vessels (Springer et al., 1998; Pola et al., 2001). This stresses the role of the tissuerelated cell type to create a microenvironment with adequate presentation, distribution and dosage of molecules and the importance of direct heterotypic interaction. Promoting interaction between the cell types involved using up-stream mediators (HIF-1alpha is a classical target) or indirect factors may push the tissue itself to produce the proper microenvironment for vascular organization and stabilization. Signals between the vascular cells and the tissue-related cells mostly remain to be 
assessed and might include the production of direct or indirect factors, direct cell-cell interactions, matrix production as a bed for EC sprouting and the generation of forces on a large-scale.

\section{Vessel Maturation Is Essential}

A current limitation of the prevascularization concept resides in the in vitro maturation and stabilization of the vasculature. Both in vivo and in vitro, clues accumulate indicating that immature microvessels have (i) a limited potential to anastamose to the host vasculature (Rouwkema et al., 2006) (Figure 5) and (ii) are prone to regression (Koike et al., 2004). Physiological observation of immature vascular network shows they are more fragile, leaky, close to some pathological conditions (Benjamin et al., 1999; Hellstrom et al., 2001; Lindahl et al., 1997) and can lead, after implantation, to the formation of oedema (Jain, 2003; Lindahl et al., 1997). In a study by Nör et al., one capillary on five, produced in vitro, was perfused in vivo and nonfunctional capillary-like structures regressed and finally disappeared within 21 days. Current knowledge suggests that networks must be in a mature stage prior to implantation or rapidly go through remodelling processes in vitro to become mature and functional in vivo. It implies the addition of $\mathrm{MC}, \mathrm{MC}$ precursors or the differentiation of tissue-related cell types into MC. MC which are recruited by the EC through TGF $\beta$ and PDGF signaling play a role in stabilization by producing ECM to provide structural integrity and by secreting survival factors to inhibit apoptosis of endothelial cells (Levenberg et al., 2005; Ramsauer et al., 2007). They are directly contributing to EC organization (Kunz-Schughart et al., 2006; Darland et al., 2003; Caspi et al., 2007). The pericyte-to-endothelial cell ratio can vary from $1: 100$ in skeletal muscle to $1: 1$ in the retina (Armulik et al., 2007): this reflects the heterogeneity of the phenotype of vessels and illustrates the complexity of the in vitro organdependent maturation of the vasculature. Interestingly; those early works bring new insights into basic questions in vascular biology: the recruitment of MC proved to induce, in classical vascular biology models, an important decrease in EC proliferation (Antonelli-Orlidge et al., 1989). In their study, Caspi et al. (2007), however, showed that, in a more complex system including a surrounding tissue, the addition of MEF increased proliferation of EC and stabilized vessels.

\section{Concluding Remarks and Perspectives}

From those early - proof of concept - works emerged paradigms on the large scale organization of tissues with a vasculature; the next generation of constructs must prove additional benefits. The integration to the surrounding organ, the trophic effect of prevascularization on surrounding tissue differentiation along with the remodelling of the vasculature after implantation are of particular interest. Further organ specific maturation of the vasculature is essential for physiological function. Continuous capillaries in muscle, fenestrated capillaries

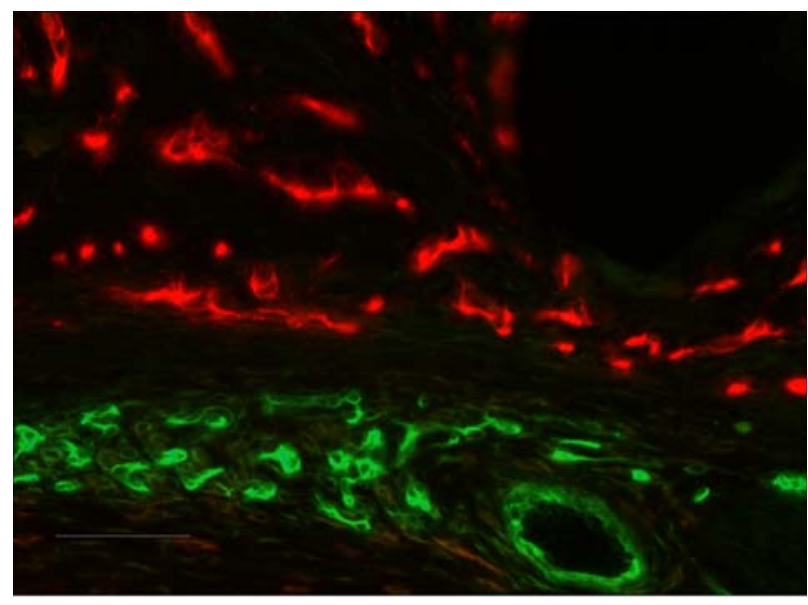

Figure 5: The interface between the scaffold and the surrounding tissue after two weeks subcutaneous implantation in immunodeficient mice shows limited connection to the host vasculature. Red is the human endothelial marker cd31. Before explantation, lectin (green) was injected into the blood system of the mice to reveal the mouse vasculature. Scale bar: $200 \mu \mathrm{m}$.

in kidney or capillaries including tight junctions for permeability to various molecules at the blood-brain or blood-retina barrier or responsive to vasoactive stimuli (arterial-venous system) are typical of a more mature stage. Prevascularized constructs provide models to uncover links between tissues through cell cooperation, tissue differentiation or tissue organization. Mechanical stimuli, shear stress and interstitial flow are known to enhance the polarity of endothelial cells and form instructive physical and biochemical gradients and represent additional stimuli that must be investigated (Sieminski et al., 2004; Helm et al., 2005; Inoguchi et al., 2007). Since capillary morphogenesis results from a combination of biomolecular and mechanical clues, those prevascularized constructs should benefit from the use of, for instance, bioreactor technology. Finally, prevascularized tissues also provide an interesting and effective tool to study physiology and physiopathologies of the vasculature in a more complex tissue context; that is in a non-endotheliocentric system.

\section{References}

Aase K, von Euler G, Li X, Ponten A, Thoren P, Cao R, Cao Y, Olofsson B, Gebre-Medhin S, Pekny M, Alitalo K, Betsholtz C, Eriksson U (2001) Vascular endothelial growth factor-B-deficient mice display an atrial conduction defect. Circulation 104: 358-364.

Adams RH, Alitalo K (2007) Molecular regulation of angiogenesis and lymphangio-genesis. Nat Rev Mol Cell Biol 8: 464-478.

Antonelli-Orlidge A, Saunders KB, Smith SR, D'Amore PA (1989) An activated form of transforming growth factor beta is produced by cocultures of endothelial cells and pericytes. Proc Natl Acad Sci USA. 86: 45444548 . 
Armulik A, Abramsson A, Betsholtz C (2005) Endothelial/pericyte interactions. Circ Res 97: 512-523.

Asahara T, Murohara T, Sullivan A, Silver M, van der Zee R, Li T, Witzenbichler B, Schatteman G, Isner JM. (1997) Isolation of putative progenitor endothelial cells for angiogenesis. Science 275: 964-967.

Asahara T, Masuda H, Takahashi T, Kalka C, Pastore C, Silver M, Kearne M, Magner M, Isner JM (1999a) Bone marrow origin of endothelial progenitor cells responsible for postnatal vasculogenesis in physiological and pathological neovascularization. Circ Res 85: 221-228.

Asahara T, Takahashi T, Masuda H, Kalka C, Chen D, Iwaguro H, Inai Y, Silver M, Isner JM. Asahara T, Takahashi T, Masuda H, Kalka C, Chen D, Iwaguro H, Inai Y, Silver M, Isner JM (1999b) VEGF contributes to postnatal neovascularization by mobilizing bone-marrow derived endothelial progenitor cells. EMBO J 18: $3964-$ 3972.

Bach AD, Arkudas A, Tjiawi J, Polykandriotis E, Kneser U, Horch RE, Beier JP (2006) A new approach to tissue engineering of vascularized skeletal muscle. J Cell Mol Med. 10: 716-726.

Beaudry P, Hida Y, Udagawa T, Alwayn IP, Greene AK, Arsenault D, Folkman J, Heymach JV, Ryeom S, Puder M (2007) Endothelial progenitor cells contribute to accelerated liver regeneration. J Pediatr Surg. 42: 11901198.

Bellomo D, Headrick JP, Silins GU, Paterson CA, Thomas PS, Gartside M, Mould A, Cahill MM, Tonks ID, Grimmond SM, Townson S, Wells C, Little M, Cummings MC, Hayward NK, Kay GF (2000) Mice lacking the vascular endothelial growth factor-B gene (Vegfb) have smaller hearts, dysfunctional coronary vasculature, and impaired recovery from cardiac ischemia. Circ Res 86: E29-E35.

Benjamin LE, Golijanin D, Itin A, Pode D, Keshet E (1999) Selective ablation of immature blood vessels in established human tumors follows VEGF withdrawal. J Clin. Invest 103: 159-165.

Blau HM, Banfi A (2001) The well-tempered vessel. Nat Med. 7: 532-534.

Black AF, Berthod F, L'heureux N, Germain L, Auger FA. (1998) In vitro reconstruction of a human capillarylike network in a tissue-engineered skin equivalent. FASEB J. 12: 1331-1340.

Bouletreau PJ, Warren SM, Spector JA, Peled ZM, Gerrets RP, Greenwald JA, Longaker MT (2002) Hypoxia and VEGF up-regulate BMP-2 mRNA and protein expression in microvascular endothelial cells: implications for fracture healing. Plast Reconstr Surg 109: 2384-2397.

Brittberg M, Lindahl A, Nilsson A, Ohlsson C, Isaksson O, Peterson L (1994) Treatment of deep cartilage defects in the knee with autologous chondrocyte transplantation. N Engl J Med 331: 889-895.

Campochiaro, P. A (2004) Ocular neovascularisation and excessive vascular permeability. Expert Opin Biol Ther 4: 1395-1402.

Carano RA, Filvaroff EH (2003) Angiogenesis and bone repair. Drug Discov Today 8: 980-989.

Carmeliet P (2005) Angiogenesis in life, disease and medicine. Nature 438: 932-936.
Carmeliet P, Jain RK (2000) Angiogenesis in cancer and other diseases. Nature. 407: 249-257.

Carmeliet P, Ferreira V, Breier G, Pollefeyt S, Kieckens L, Gertsenstein M, Fahrig M, Vandenhoeck A, Harpal K, Eberhardt C, Declercq C, Pawling J, Moons L, Collen D, Risau W, Nagy A (1996) Abnormal blood vessel development and lethality in embryo lacking a single VEGF allele. Nature 380: 435-439.

Carrier RL, Papadaki M, Rupnick M, Schoen FJ, Bursac N, Langer R, Freed LE, Vunjak-Novakovic G (1999). Cardiac tissue engineering: Cell seeding, cultivation parameters and tissue construct characterization. Biotechnol Bioeng 64: 580-589.

Carrier RL, Rupnick M, Langer R, Schoen FJ, Freed LE, Vunjak-Novakovic G. 2002. Perfusion improves tissue architecture of engineered cardiac muscle. Tissue Eng 8: 175-188.

Caspi O, Lesman A, Basevitch Y, Gepstein A, Arbel G, Habib IH, Gepstein L, Levenberg S (2007) Tissue engineering of vascularized cardiac muscle from human embryonic stem cells. Circ Res 100: 263-272.

Cassell OC, Morrison WA, Messina A, Penington AJ, Thompson EW, Stevens GW, Perera JM, Kleinman HK, Chrobak KM, Potter DR, Tien J (2006) Formation of perfused, functional microvascular tubes in vitro. Microvasc Res 71: 185-196.

Campochiaro PA (2004) Ocular neovascularisation and excessive vascular permeability. Expert Opin Biol Ther 4:1395-1402.

Chrobak KM, Potter DR, Tien J (2006) Formation of perfused, functional microvascular tubes in vitro. Microvasc Res. 71:185-196.

Colton CK (1995) Implantable biohybrid artificial organs. Cell Transplantation. 4: 415-436.

Conway EM, Carmeliet P (2004) The diversity of endothelial cells: a challenge for therapeutic angiogenesis. Genome Biol 5: 207.

Crosby JR, Kaminski WE, Schatteman G, Martin PJ, Raines EW, Seifert RA, Bowen-Pope DF (2000) Endothelial cells of hematopoietic origin make a significant contribution to adult blood vessel formation. Circ Res 87: 728-730.

Darland DC, Massingham LJ, Smith SR, Piek E, SaintGeniez M, D'Amore PA (2003) Pericyte production of cellassociated VEGF is differentiation-dependent and is associated with endothelial survival. Dev Biol 264: 275288.

Darland DC, D'Amore PA. Darland DC, D'Amore PA (2001) TGF beta is required for the formation of capillarylike structures in three-dimensional cocultures of 10T1/2 and endothelial cells. Angiogenesis 4: 11-20.

Deckers MM, Karperien M, van der Bent C, Yamashita T, Papapoulos SE, Löwik CW (2000) Expression of vascular endothelial growth factors and their receptors during osteoblast differentiation. Endocrinology 141: 1667-1674.

De Palma M, Venneri MA, Roca C, Naldini L (2003) Targeting exogenous genes to tumor angiogenesis by transplantation of genetically modified hematopoietic stem cells. Nat Med 9: 789-795. 
Dickson MC, Martin JS, Cousins FM, Kulkarni AB, Karlsson S, Akhurst RJ (1995) Defective haematopoiesis and vasculogenesis in transforming growth factor-beta 1 knock out mice. Development. 121: 1845-1854.

Ding R, Darland DC, Parmacek MS, D'Amore PA (2004) Endothelial-mesenchymal interactions in vitro reveal molecular mechanisms of smooth muscle/pericyte differentiation. Stem Cells Dev 13: 509-520.

Drake CJ, Hungerford JE, Little CD (1998) Morphogenesis of the first blood vessels. Ann. NY Acad Sci 857: 155-179.

Dumont DJ, Jussila L, Taipale J, Lymboussaki A, Mustonen T, Pajusola K, Breitman M, Alitalo K (1998) Cardiovascular failure in mouse embryos deficient in VEGF receptor-3. Science 282: 946-949.

Edelberg JM, Tang L, Hattori K, Lyden D, Rafii S (2002) Young adult bone marrow-derived endothelial precursor cells restore aging-impaired cardiac angiogenic function. Circ Res 90: E89-E93.

Erol OO, Spira M (1979) New capillary bed formation with a surgically constructed arteriovenous fistula. Surg Forum 30: 530-531.

Ferrara N, Carver-Moore K, Chen H, Dowd M, Lu L, O'Shea KS, Powell-Braxton L, Hillan KJ, Moore MW (1996) Heterozygous embryonic lethality induced by targeted inactivation of the VEGF gene. Nature 380: 439442.

Folkman J (2007) Is angiogenesis an organizing principle in biology and medicine? J Pediatr Surg 42: 111.

Folkman J (1971) Tumor angiogenesis: therapeutic implications. N Engl J Med 285: 1182-1186.

Fong GH, Rossant J, Gertsenstein M, Breitman ML (1995) Role of the Flt-1 receptor tyrosine kinase in regulating the assembly of vascular endothelium. Nature 376: $66-70$.

Francis SE, Goh KL, Hodivala-Dilke K, Bader BL, Stark M, Davidson D, Hynes RO (2002) Central roles of a5b1 integrin and fibronectin in vascular development in mouse embryos and embryoid bodies. Arterioscler Thromb Vasc Biol 22: 927-933.

Furumatsu T, Shen ZN, Kawai A, Nishida K, Manabe H, Oohashi T, Inoue H, Ninomiya Y (2003) Vascular endothelial growth factor principally acts as the main angiogenic factor in the early stage of human osteoblastogenesis, J Biochem (Tokyo) 133: 633-639.

Gill M, Dias S, Hattori K, Rivera ML, Hicklin D, Witte L, Girardi L, Yurt R, Himel H, Rafii S (2001) Vascular trauma induces rapid but transient mobilization of VEGFR2(+)AC133(+) endothelial precursor cells. Circ Res 88: 167-174.

Greene HSN (1961) Heterologous transplantation of mammalian tumors. Exp Med 73: 461.

Griffith CK, Miller C, Sainson RC, Calvert JW, Jeon NL, Hughes CC, George SC (2005) Diffusion limits of an in vitro thick prevascularized tissue. Tissue Eng 11: 257 266.

Griffith LG, Naughton G (2002) Tissue engineering current challenges and expanding opportunities. Science 295: 1009-1014.
Hausman MR, Rinker BD (2004) Intractable wounds and infections: the role of impaired vascularity and advanced surgical methods for treatment. Am J Surg 187: 44S-55S.

Hausman MR, Schaffler MB, Majeska RJ (2001) Prevention of fracture healing in rats by an inhibitor of angiogenesis. Bone 29: 560-564.

He Y, Rajantie I, Ilmonen M, Makinen T, Karkkainen MJ, Haiko P, Salven P, Alitalo K (2004) Preexisting lymphatic endothelium but not endothelial progenitor cells are essential for tumor lymphangiogenesis and lymphatic metastasis. Cancer Res 64: 3737-3740.

Hellström M, Gerhardt H, Kalén M, Li X, Eriksson U, Wolburg H, Betsholtz C (2001) Lack of pericytes leads to endothelial hyperplasia and abnormal vascular morphogenesis. J Cell Biol 153: 543-553.

Helm CL, Fleury ME, Zisch AH, Boschetti F, Swartz MA. Helm CL, Fleury ME, Zisch AH, Boschetti F, Swartz MA (2005) Synergy between interstitial flow and VEGF directs capillary morphogenesis in vitro through a gradient amplification mechanism. Proc Natl Acad Sci USA 102: 15779-15784.

Heissig B, Hattori K, Dias S, Friedrich M, Ferris B, Hackett NR, Crystal RG, Besmer P, Lyden D, Moore MA, Werb Z, Rafii S. Heissig B, Hattori K, Dias S, Friedrich M, Ferris B, Hackett NR, Crystal RG, Besmer P, Lyden D, Moore MA, Werb Z, Rafii S (2002) Recruitment of stem and progenitor cells from the bone marrow niche requires MMP-9 mediated release of kitligand. Cell 109: 625-637.

Hirschi KK, Skalak TC, Peirce SM, Little CD (2002) Vascular assembly in natural and engineered tissues. Ann N Y Acad Sci 961: 223-242.

Hofer SO, Knight KM, Cooper-White JJ, O'Connor AJ, Perera JM, Romeo-Meeuw R, Penington AJ, Knight KR, Morrison WA, Messina A (2003) Increasing the volume of vascularized tissue formation in engineered constructs: an experimental study in rats. Plast Reconstr Surg 3: 1186-1192.

Hung SC, Pochampally RR, Hsu SC, Sanchez C, Chen SC, Spees J, Prockop DJ (2007) Short-term exposure of multipotent stromal cells to low oxygen increases their expression of CX3CR1 and CXCR4 and their engraftment in vivo. PLoS ONE. 2: e416.

Inoguchi H, Tanaka T, Maehara Y, Matsuda T (2007) The effect of gradually graded shear stress on the morphological integrity of a huvec-seeded compliant small-diameter vascular graft. Biomaterials 28: 486-495.

Ishaug-Riley SL, Crane-Kruger GM, Yaszemski MJ, Mikos AG (1998) Three-dimensional culture of rat calvarial osteoblasts in porous biodegradable polymers. Biomaterials 19: 1405-1412.

Isner JM, Pieczek A, Schainfeld R, Blair R, Haley L, Asahara T, Rosenfield K, Razvi S, Walsh K, Symes JF (1996) Clinical evidence of angiogenesis after arterial gene transfer of phVEGF165 in patient with ischemia limb. Lancet 348: 370-374.

Jain RK (2003) Molecular regulation of vessel maturation. Nat Med 9: 685-693.

Jesmin S, Hattori Y, Togashi H, Ueno K, Yoshioka M, Sakuma I (2005) Age-related changes in cardiac expression 
of VEGF and its angiogenic receptor KDR in stroke-prone spontaneously hypertensive rats. Mol Cell Biochem 272: 63-73.

Kaigler D, Krebsbach PH, Polverini PJ, Mooney DJ (2003) Role of vascular endothelial growth factor in bone marrow stromal cell modulation of endothelial cells, Tissue Eng 9: 95-103.

Kannan RY, Salacinski HJ, Sales K, Butler P, Seifalian AM (2005) The roles of tissue engineering and vascularisation in the development of micro-vascular networks: a review. Biomaterials 26: 1857-1875.

Kelm JM, Djonov V, Ittner LM, Fluri D, Born W, Hoerstrup SP, Fussenegger M (2006) Design of customshaped vascularized tissues using microtissue spheroids as minimal building units. Tissue Eng 12: 2151-2160.

Khouri RK, Hong SP, Deune EG, Tarpley JE, Song SZ, Serdar CM, Pierce GF (1994) De novo generation of permanent neovascularized soft tissue appendages by platelet derived growth factor. J Clin Invest 94:1757-1763.

Kirsner RS, Falanga V, Eaglstein WH (1998) The development of bioengineered skin. Trends Biotechnol 16: 246-249.

Kneser U, Polykandriotis E, Ohnolz J, Heidner K, Grabinger L, Euler S, Aman KU, Hess A, Brune K, Greil P, Sturzl M, Horch RE. (2006a) Engineering of vascularized transplantable bone tissues: induction of axial vascularization in an osteconductive matrix using an arteriovenous loop. Tissue Eng 12: 1721-1731.

Kneser U, Arkudas A, Polykandriotis E, Heidner K, Ohnolz J, Beier JP, Bach AD, Kopp J, Hess A, Horch RE (2006b) Axial prevascularization of porous matrices by means of an arteriovenous loop significantly increases initial survival of transplanted autologous osteoblasts. Tissue Eng 13: 1549-1560.

Kneser U, Schaefer DJ, Polykandriotis E, Horch RE (2006c) Tissue engineering of bone: the reconstructive surgeon's point of view. J Cell Mol Med 10: 7-19.

Ko IK, Iwata H (2001) An approach to constructing three-dimensional tissue. Ann N Y Acad Sci 944: 443-455.

Koike N, Fukumura D, Gralla O, Au P, Schechner JS, Jain RK (2004) Tissue engineering: creation of long-lasting blood vessels. Nature 428: 138-139.

Kramer R, Bucay N, Kane DJ, Martin LE, Tarpley JE, Theill LE. Kramer R, Bucay N, Kane DJ, Martin LE, Tarpley JE, Theill LE (1996) Neuregulins with an Ig-like domain are essential for mouse myocardial and neuronal development. Proc Natl Acad Sci USA. 93: 4833-4838.

Kruyt MC, de Bruijn JD, Yuan H, van Blitterswijk CA, Verbout AJ, Oner FC, Dhert WJ (2004) Optimization of bone tissue engineering in goats: a peroperative seeding method using cryopreserved cells and localized bone formation in calcium phosphate scaffolds. Transplantation 77: 359-365.

Kunz-Schughart LA, Schroeder JA, Wondrak M, van Rey F, Lehle K, Hofstaedter F, Wheatley DN (2006) Potential of fibroblasts to regulate the formation of threedimensional vessel-like structures from endothelial cells in vitro. Am J Physiol Cell Physiol 290: C1385-1398.

Lammert E, Cleaver O, Melton D (2001) Induction of pancreatic differenciation by signals from blood vessels. Science 294: 564-567.
Langer R, Vacanti JP (1993) Tissue engineering, Science 260: 920-926.

Levéen P, Pekny M, Gebre-Medhin S, Swolin B, Larsson E, Betsholtz C (1994) Mice deficient for PDGF B show renal, cardiovascular, and hematological abnormalities. Genes Dev 8: 1875-1887.

Levenberg S, Rouwkema J, Macdonald M, Garfein ES, Kohane DS, Darland DC, Marini R, van Blitterswijk CA, Mulligan RC, D'Amore PA, Langer R (2005) Engineering vascularized skeletal muscle tissue. Nat Biotechnol 23: 879-884.

Levy AP, Levy NS, Goldberg MA. (1996) Hypoxia inducible protein binding to vascular endothelial growth factor mRNA and its modulation by the Von Hippel Lindau protein. J Biol Chem 271: 25492-25497.

Lewis MC, MacArthur BD, Malda J, Pettet G, Please CP (2005) Heterogeneous growth of engineered cartilaginous tissue: The role of oxygen tension. Biotechnol Bioeng 91: 607-615.

L'Heureux N, Dusserre N, Konig G, Victor B, Keire P, Wight TN, Chronos NA, Kyles AE, Gregory CR, Hoyt G, Robbins RC, McAllister TN (2006) Human tissueengineered blood vessels for adult arterial revascularization. Nat Med 12: 361-365.

Li DY, Sorensen LK, Brooke BS, Urness LD, Davis EC, Taylor DG, Boak BB, Wendel DP (1999) Defective angiogenesis in mice lacking endoglin. Science 284: 15341527.

Li J, Post M, Volk R, Gao Y, Li M, Metais C, Sato K, Tsai J, Aird W, Rosenberg RD, Hampton TG, Sellke F, Carmeliet P, Simons M (2000) PR39 a peptide regulator of angiogenesis. Nat Med 6: 49-55.

Lindahl P, Johansson BR, Levéen P, Betsholtz C (1997) Pericyte loss and microaneurysm formation in PDGF-Bdeficient mice. Science 277: 242-245.

Losordo DW, Vale PR, Hendel RC, Milliken CE, Fortuin FD, Cummings N, Schatz RA, Asahara T, Isner JM, Kuntz RE (2002) Phase 1/2 placebo-controlled, double-blind, dose-escalating trial of myocardial vascular endothelial growth factor 2 gene transfer by catheter delivery in patients with chronic myocardial ischemia. Circulation 105: 2012-2018.

Lutolf MP, Lauer-Fields JL, Schmoekel HG, Metters AT, Weber FE, Fields GB, Hubbell JA (2003) Synthetic matrix metalloproteinase-sensitive hydrogels for the conduction of tissue regeneration: engineering cellinvasion characteristics. Proc Natl Acad Sci 100: 54135418.

Lyden D, Hattori K, Dias S, Costa C, Blaikie P, Butros L, Chadburn A, Heissig B, Marks W, Witte L, Wu Y, Hicklin D, Zhu Z, Hackett NR, Crystal RG, Moore MA, Hajjar KA, Manova K, Benezra R, Rafii S (2001) Impaired recruitment of bone-marrow-derived endothelial and hematopoietic precursor cells blocks tumor angiogenesis and growth. Nat Med 7: 1194-1201.

Maes C, Stockmans I, Moermans K, Van Looveren R, Smets N, Carmeliet P, Bouillon R, Carmeliet G (2004) Soluble VEGF isoforms are essential for establishing epiphyseal vascularization and regulating chondrocyte development and survival. J Clin Invest 113: 188-199. 
Maisonpierre PC, Suri C, Jones PF, Bartunkova S, Wiegand SJ, Radziejewski C, Compton D, McClain J, Aldrich TH, Papadopoulos N, Daly TJ, Davis S, Sato TN, Yancopoulos GD (1997) Angiopoietin-2, a natural antagonist for Tie2 that disrupts in vivo angiogenesis. Science 277: 55-60.

Martínez P, Esbrit P, Rodrigo A, Alvarez-Arroyo MV, Martínez ME (2002) Age-related changes in parathyroid hormone-related protein and vascular endothelial growth factor in human osteoblastic cells. Osteoporos Int 13: 874881.

McDowell F (1978) Plastic surgery in the twentieth century. Ann Plast Surg 1: 217-224.

Messina A, Bortolotto SK, Cassell OC, Kelly J, Abberton KM, Morrison WA (2005) Generation of a vascularized organoid using skeletal muscle as the inductive source. FASEB J 19: 1570-1572.

Meyer D, Birchmeier C (1995) Multiple essential functions of neuregulin in development. Nature 378: 386390.

Moldovan NI (2005) Angiogenesis, l'enfant terrible of vascular biology is coming of age. J Cell Mol Med 9: 775-776.

Mooney DJ, Mikos AG (1999) Growing new organs. Sci Am 280: 60-65.

Mori S, Yoshikawa H, Hashimoto J, Ueda T, Funai H, Kato M, Takaoka K (1998) Antiangiogenic agent (TNP470) inhibition of ectopic bone formation induced by bone morphogenic protein-2. Bone 22: 99-105.

Morrison WA, Dvir E, Doi K, Hurley JV, Hickey MJ, O'Brien BM (1990) Prefabrication of thin transferable axialpattern skin flaps: an experimental study in rabbits. Br J Plast Surg 43: 645-654.

Murphy WL, Peters MC, Kohn DH, Mooney DJ. (2000) Sustained release of vascular endothelial growth factor from mineralized poly(lactide-co-glycolide) scaffolds for tissue engineering. Biomaterials 21: 25212527.

Muschler GF, Nakamoto C, Griffith LG (2004) Engineering principles of clinical cell-based tissue engineering. Bone Joint Surg Am 86A: 1541-1558.

Nör JE, Peters MC, Christensen JB, Sutorik MM, Linn S, Khan MK, Addison CL, Mooney DJ, Polverini PJ (2001) Engineering and characterization of functional human microvessels in immunodeficient mice. Lab Invest 81: 453-463.

Oshima M (1996) TGF-beta receptor type II deficiency results in defects of yolk sac hematopoiesis and vasculogenesis. Dev Biol 179: 297-302.

Papadaki M, Bursac N, Langer R, Merok J, VunjakNovakovic G, Freed LE (2001) Tissue engineering of functional cardiac muscle: Molecular, structural and electrophysiological studies. Am J Physiol Heart Circ Physiol 280: 168-178.

Peters K (2003) Molecular basis of endothelial dysfunction in sepsis. Cardiovasc Res 60: 49-57.

Pola R, Ling LE, Silver M, Corbley MJ, Kearney M, Blake Pepinsky R, Shapiro R, Taylor FR, Baker DP, Asahara T, Isner JM (2001) The morphogen Sonic hedgehog is an indirect angiogenic agent upregulating two families of angiogenic growth factors. Nat Med 7: 706711.

Polverini PJ (2002) Angiogenesis in health and disease: insights into basic mechanisms and therapeutic opportunities. J Dent Educ 66: 962-975.

Pufe T, Scholz-Ahrens KE, Franke AT, Petersen W, Mentlein R, Varoga D, Tillmann B, Schrezenmeir J, Glüer CC. (2003) The role of vascular endothelial growth factor in glucocorticoid-induced bone loss: evaluation in a minipig model. Bone 33: 869-876.

Radisic M, Park H, Shing H, Consi T, Schoen FJ, Langer R, Freed LE, Vunjak-Novakovic G (2004a) Functional assembly of engineered myocardium by electrical stimulation of cardiac myocytes cultured on scaffolds. Proc Natl Acad Sci USA 101: 18129-18134.

Radisic M, Yang L, Boublik J, Cohen RJ, Langer R, Freed LE, Vunjak-Novakovic G (2004b) Medium perfusion enables engineering of compact and contractile cardiac tissue. Am J Physiol Heart Circ Physiol 286: 507516.

Radisic M, Malda J, Epping E, Geng W, Langer R, Vunjak-Novakovic G (2006) Oxygen gradients correlate with cell density and cell viability in engineered cardiac tissue. Biotechnol Bioeng 93: 3323-3343.

Rajantie I, Ilmonen M, Alminaite A, Ozerdem U, Alitalo K, Salven P (2004) Adult bone marrow-derived cells recruited during angiogenesis comprise precursors for periendothelial vascular mural cells. Blood 104: 20842086.

Ramsauer M, D'Amore PA (2007) Contextual role for angiopoietins and TGFbeta1 in blood vessel stabilization. J Cell Sci 120: 1810-1817.

Red-Horse K, Crawford Y, Shojaei F, Ferrara N (2007) Endothelium-microenvironment interactions in the developing embryo and in the adult. Dev Cell 12:181-194.

Reinmuth N, Liu W, Jung YD, Ahmad SA, Shaheen RM, Fan F, Bucana CD, McMahon G, Gallick GE, Ellis LM (2001) Induction of vegf in perivascular cells defines a potential paracrine mechanism for endothelial cell survival. FASEB J 15: 1239-1241.

Richardson TP, Peters MC, Ennett AB, Mooney DJ (2001) Polymeric system for dual growth factor delivery. Nat Biotechnol 19: 1029-1034.

Rouwkema J, de Boer J, Van Blitterswijk CA. (2006) Endothelial cells assemble into a 3-dimensional prevascular network in a bone tissue engineering construct. Tissue Eng. 12: 2685-93.

Sato TN, Tozawa Y, Deutsch U, Wolburg-Buchholz K, Fujiwara Y, Gendron-Maguire M, Gridley T, Wolburg H, Risau W, Qin Y (1995) Distinct roles of the receptor tyrosine kinases Tie-1 and Tie-2 in blood vessel formation. Nature 376: 70-74.

Scherberich A, Galli R, Jaquiery C, Farhadi J, Martin I. (2007) Three-dimensional perfusion culture of human adipose tissue-derived endothelial and osteoblastic progenitors generates osteogenic constructs with intrinsic vascularization capacity. Stem Cells 25: 1823-1829.

Schechner JS, Nath AK, Zheng L, Kluger MS, Hughes CC, Sierra-Honigmann MR, Lorber MI, Tellides G, Kashgarian M, Bothwell AL, Pober JS (2000) In vivo 
formation of complex microvessels lined by human endothelial cells in an immunodeficient mouse. Proc Natl Acad Sci USA 97: 9191-9196.

Shalaby F, Rossant J, Yamaguchi TP, Gertsenstein M, Wu XF, Breitman ML, Schuh AC (1995) Failure of blood island formation and vasculogenesis in Flk1 deficient mice. Nature 376: 62-66.

Shepherd BR, Enis DR, Wang F, Suarez Y, Pober JS, Schechner JS (2006) Vascularization and engraftment of a human skin substitute using circulating progenitor cellderived endothelial cells. FASEB J 20: 1739-1741.

Shi Q, Rafii S, Wu MH, Wijelath ES, Yu C, Ishida A, Fujita Y, Kothari S, Mohle R, Sauvage LR, Moore MA, Storb RF, Hammond WP (1998) Evidence of circulating bone-marrow derived endothelial cells. Blood 92: 362-367.

Shin'oka, T., Imai, Y., and Ikada, Y. (2001) Transplantation of a tissue-engineered pulmonary artery. N. Engl. J Med. 344: 532-533.

Shima DT, Adamis AP, Ferrara N, Yeo KT, Yeo TK, Allende R, Folkman J, D’Amore PA (1995) Hypoxic induction of endothelial cell growth factors in retina cells: identification and characterization of VEGF as the mitogen. Mol Med 1: 182-193.

Shweiki D, Itin A, Soffer D, Keshet E (1992) VEGF induced by hypoxia may mediate hypoxia-initiated angiogenesis. Nature 359: 843-848.

Sieminski AL, Hebbel RP, Gooch KJ (2004) The relative magnitudes of endothelial force generation and matrix stiffness modulate capillary morphogenesis in vitro. Exp Cell Res 297: 574-584.

Skalak R, Fox CF (1988) Proceedings for a workshop held at Granlibakken, Lake Tahoe, California. Tissue Eng 26-29.

Springer ML, Chen AS, Kraft PE, Bednarski M, Blau HM (1998) VEGF gene delivery to muscle, potential role for vasculogenesis in adults. Mol Cell 2: 549-558.

Stahl A, Wenger A, Weber H, Stark GB, Augustin HG, Finkenzeller G (2004) Bi-directional cell contactdependent regulation of gene expression between endothelial cells and osteoblasts in a three-dimensional spheroidal coculture model. Biochem Biophys Res Commun 322: 684-692.

Stein I, Neeman M, Shweiki D, Itin A, Keshet E (1995) Stabilization of VEGF mRNA by hypoxia and hypoglycemia and coregulation with other ischemia induced gene. Mol Cell Biol 15: 5363-5368.

Soriano P (1994) Abnormal kidney development and hematological disorders in PDGF beta-receptor mutant mice. Genes Dev 8: 1888-1896.

Shiojima I, Sato K, Izumiya Y, Schiekofer S, Ito M, Liao R, Colucci WS, Walsh K (2005) Disruption of coordinated cardiac hypertrophy and angiogenesis contributes to the transition to heart failure. J Clin Invest 115: 2108-2118.

Stainier DY, Weinstein BM, Detrich HW 3rd, Zon LI, Fishman MC (1995) Cloche, an early acting zebrafish gene, is required by both the endothelial and hematopoietic lineages. Development 121: 3141-3150.

Suri C, Jones PF, Patan S, Bartunkova S, Maisonpierre PC, Davis S, Sato TN, Yancopoulos GD (1996) Requisite role of angiopoietin-1, a ligand for the TIE2 receptor, during embryonic angiogenesis. Cell 87: 1171-1180.

Suzuki K, Bonner-Weir S, Hollister-Lock J, Colton CK, Weir GC (1998) Number and volume of islets transplanted in immunobarrier devices. Cell Transplant 7: 47-52.

Takahashi T, Kalka C, Masuda H, Chen D, Silver M, Kearney M, Magner M, Isner JM, Asahara T (1999) Ischemia and cytokine induced mobilization of bone marrow derived endothelial progenitor cells for neovascularization. Nat Med 5: 434-438.

Tanaka, Y, Tajima, S, Tsutsumi, A, Akamatsu, J, Ohba S (1996), New matrix flap prefabricated by arteriovenous shunting and artificial skin dermis in rats. J. Jpn Plast Reconstr Surg. 16: 679-686.

Tanaka Y, Tsutsumi A, Crowe DM, Tajima S, Morrison WA (2000) Generation of an autologous tissue (matrix) flap by combining arteriovenous shunt loop with artificial skin in rats: preliminary report. Br J Plast Surg 53: 51-57.

Tanaka Y, Sung KC, Fumimoto M, Tsutsumi A, Kondo S, Hinohara Y, Morrison WA (2006) Prefabricated engineered skin flap using an arteriovenous vascular bundle as a vascular carrier in rabbits. Plast Reconstr Surg 117: 1860-1875.

Terheyden H, Warnke P, Dunsche A, Jepsen S, Brenner W, Palmie S, Toth C, Rueger DR (2001) Mandibular reconstruction with prefabricated vascularized bone grafts using recombinant human osteogenic protein-1: an experimental study in miniature pigs. Part II: Transplantation. Int J Oral Maxillofac Surg 30: 469-478.

Terheyden H, Menzel C, Wang H, Springer IN, Rueger DR, Acil Y(2004) Prefabrication of vascularized bone grafts using recombinant human osteogenic protein-1 - part 3: dosage of rhOP-1, the use of external and internal scaffolds. Int J Oral Maxillofac Surg 33: 164-172.

Tremblay PL, Hudon V, Berthod F, Germain L, Auger FA (2005) Inosculation of tissue-engineered capillaries with the host's vasculature in a reconstructed skin transplanted on mice. Am J Transplant 5: 1002-1010.

Tsai AG, Johnson PC, Intaglietta M (2003) Oxygen gradients in the microcirculation. Physiol Rev 83: 933963.

Urbich C, Heeschen C, Aicher A, Dernbach E, Zeiher AM, Dimmeler S (2003) Relevance of monocytic features for neovascularization capacity of circulating endothelial progenitor cells. Circulation 108: 2511-2516.

Unger RE, Sartoris A, Peters K, Motta A, Migliaresi C, Kunkel M, Bulnheim U, Rychly J, Kirkpatrick CJ (2007) Tissue-like self-assembly in cocultures of endothelial cells and osteoblasts and the formation of microcapillary-like structures on three-dimensional porous biomaterials. Biomaterials 28: 3965-3976.

Villars F, Bordenave L, Bareille R, Amédée J (2000) Effect of human endothelial cells on human bone marrow stromal cell phenotype: role of VEGF? J Cell Biochem 79: 672-685.

Vincent KA, Shyu KG, Luo Y, Magner M, Tio RA, Jiang C, Goldberg MA, Akita GY, Gregory RJ, Isner JM (2000) Angiogenesis is induced in a rabbit model of hindlimb ischemia by naked DNA encoding an HIF1alpha/VP16 hybrid transcription factor. Circulation 102: 2255-2261. 
Von Schroeder HP, Veillette CJ, Payandeh J, Qureshi A, Heersche JN (2003) Endothelin-1 promotes osteoprogenitor proliferation and differentiation in fetal rat calvarial cell cultures. Bone 33: 673-684.

Voswinckel R, Ziegelhoeffer T, Heil M, Kostin S, Breier G, Mehling T, Haberberger R, Clauss M, Gaumann A, Schaper W, Seeger W (2003) Circulating vascular progenitor cells do not contribute to compensatory lung growth. Circ Res 93: 372-379.

Wagers AJ, Sherwood RI, Christensen JL, Weissman IL (2002) Little evidence for developmental plasticity of adult hematopoietic stem cells. Science 297: 2256-2259.

Wang DS, Miura M, Demura H, Sato K (1997) Anabolic effects of 1,25-dihydroxy-vitamin D3 on osteoblasts are enhanced by vascular endothelial growth factor produced by osteoblasts and by growth factors produced by endothelial cells. Endocrinology 138: 29532962.

Warnke PH, Springer IN, Wiltfang J, Acil Y, Eufinger H, Wehmöller M, Russo PA, Bolte H, Sherry E, Behrens E, Terheyden H (2004) Growth and transplantation of a custom vascularised bone graft in a man. Lancet 364: 766770 .

Wenger A, Stahl A, Weber H, Finkenzeller G, Augustin HG, Stark GB, Kneser U (2004) Modulation of in vitro angiogenesis in a three-dimensional spheroidal coculture model for bone tissue engineering, Tissue Engineering 10: 1536-1547.

Wu X, Rabkin-Aikawa E, Guleserian KJ, Perry TE, Masuda Y, Sutherland FW, Schoen FJ, Mayer JE Jr, Bischoff J (2004) Tissue-engineered microvessels on threedimensional biodegradable scaffolds using human endothelial progenitor cells. Am J Physiol Heart Circ Physiol 287: 480-487.

Yang J, Nagavarapu U, Relloma K, Sjaastad MD, Moss WC, Passaniti A, Herron GS (2001) Telomerized human microvasculature is functional in vivo, Nat Biotechnol 19: 219-224.

Yin G, Liu W, An P, Li P, Ding I, Planelles V, Schwarz EM, Min W (2002) Endostatin gene transfer inhibits joint angiogenesis and pannus formation in inflammatory arthritis. Mol Ther 5: 547-554.

Ziegelhoeffer T, Fernandez B, Kostin S, Heil M, Voswinckel R, Helisch A, Schaper W (2004) Bone marrowderived cells do not incorporate into the adult growing vasculature. Circ Res 94: 230-238.

Zimmermann WH, Schneiderbanger K, Schubert P, Didié M, Münzel F, Heubach JF, Kostin S, Neuhuber WL, Eschenhagen T (2002) Tissue engineering of a differentiated cardiac muscle construct. Circ Res 90: 223230 . 